\title{
Energy pattern analysis of a wastewater treatment plant
}

\author{
Pratima Singh • Cynthia Carliell-Marquet • \\ Arun Kansal
}

Received: 28 December 2011/ Accepted: 27 April 2012/Published online: 12 May 2012

(C) The Author(s) 2012. This article is published with open access at Springerlink.com

\begin{abstract}
Various forms of energy are used during a wastewater treatment process like electrical, manual, fuel, chemical etc. Most of the earlier studies have focused only on electrical energy intensity of large-scale centralized wastewater treatment plants (WWTPs). This paper presents a methodological framework for analysing manual, mechanical, chemical and electrical energy consumption in a small-scaled WWTP. The methodology has been demonstrated on a small-scale WWTP in an institutional area. Total energy intensity of the plant is $1.046 \mathrm{kWh} / \mathrm{m}^{3}$ of wastewater treated. Electrical energy is only about half of the total energy consumption. Manual energy also has a significant share, which means that the small-scale treatment plants offer significant employment opportunities in newly industrializing countries and replaces fossil fuelbased energy with renewable. There is a lack of sufficient data in the literature for comparison, and few studies have reported values that vary significantly due to the difference in scale, scope of the study and the choice of the treatment technologies. Replication of similar studies and generation of data in this area will offer directions for decision on choice of the scale of wastewater treatment process from
\end{abstract}

P. Singh

Department of Energy and Environment, TERI University,

New Delhi, India

e-mail: prati.singh@gmail.com

C. Carliell-Marquet

Department of Civil Engineering, University of Birmingham, Birmingham, UK

e-mail: C.M.CARLIELL@bham.ac.uk

\section{A. Kansal ( $\square)$}

Department of Natural Resources, TERI University,

10 Institutional Area, Vasant Kunj, New Delhi, India

e-mail: akansal@teri.res.in the considerations of energy and climate change mitigation strategies.

Keywords Energy pattern analyses - Wastewater treatment $\cdot$ Methodological framework · Energy intensity

\section{Introduction}

The growing scarcity of water has increased the dependency of urban water system on energy, both for conveyance and treatment. Access to energy can become a hindrance to the sustainable urban cities causing both shortage of water resources and water pollution. In addition, with growing climate concerns, energy saving, energy efficiency and energy substitution have become a common development principle all over the world (Friedrich et al. 2008). In this light, urban sanitation is a sector that can have substantial energy burden and can become important for power demand estimations in the coming years. This aspect is more important in developing countries where a huge gap exists between wastewater generation and treatment. In coming years, a large number of wastewater treatment-related infrastructure projects are expected to be implemented in these countries. So far, the main factors considered in decision making of such projects are the capital and operating costs, skills required for operation, and ease of technology adaptability under local conditions. Bringing energy considerations in such decision making will offer dual advantage of energy substitution and climate change mitigation which are vital ingredients of an eco-city development program (Mahgoub et al. 2010). This aspect has an amplified relevance in countries, which are energy deficient.

In a wastewater treatment plant (WWTP), energy is used in the form of electrical, manual, chemical and petroleum. 
A number of studies on energy analysis of a WWTP have considered only the electrical form of energy (Devi et al. 2007a; Hellstrom 1997; Jonasson 2007; Merlin and Lissolo 2010; Middlebrooks et al. 1981). However, for exploring opportunities for energy efficiency and energy substitution, a detailed analysis of various forms of energy consumption is required. Such analysis should include share of various energy forms and energy intensity at various stages of treatment process. This paper presents an energy pattern analysis of a WWTP in an institutional area. More importantly, it demonstrates a methodological framework by which such studies can be replicated to generate data with respect to various scales of treatment and choice of treatment technology. This information will provide a sound basis for planning tools and answers to the growing debate of water-energy nexus, developing energy efficiency benchmarks for urban water sector and finding possibilities for the application of renewable energy to substitute conventional forms of energy.

Table 1 Characteristics of wastewater

\begin{tabular}{lll}
\hline Parameter & Inlet & Outlet \\
\hline $\mathrm{pH}$ & $4-9$ & $7.5-9$ \\
$\mathrm{COD}(\mathrm{mg} / \mathrm{l})$ & $840-890$ & $<200$ \\
$\mathrm{SS}(\mathrm{mg} / \mathrm{l})$ & $550-680$ & $<30$ \\
$\mathrm{BOD}(\mathrm{mg} / \mathrm{l})$ & $770-755$ & $<20$ \\
$\mathrm{P}(\mathrm{mg} / \mathrm{l})$ & $2-1.50$ & $<0.63$ \\
$\mathrm{~S}(\mathrm{mg} / \mathrm{l})$ & $3-2$ & $<0.8$ \\
$\mathrm{NH}_{4}(\mathrm{mg} / \mathrm{l})$ & $45-30$ & $<19$ \\
\hline
\end{tabular}

\section{Description of the study site}

The WWTP is located at TERI University, which is in an institutional area at New Delhi, India. The plant has a design capacity of $25 \mathrm{~m}^{3} /$ day and is operated for $12 \mathrm{~h}$ a day. The actual flow of wastewater during the study period is found to vary between 19 and $23 \mathrm{~m}^{3} /$ day. Primary sources of wastewater are: hostel having 60 residents, administrative block of the University and a kitchen. The plant has been designed for reuse of water for non-potable applications. It uses physico-chemical treatment method using coagulants such as caustic soda and aluminium sulphate as primary treatment and filtration, adsorption and disinfection as tertiary treatment. Biological treatment based on rotating biological contactor (RBC) is used as secondary treatment. The dried sludge is used in a nearby horticulture park and the treated water for watering plants. Table 1 gives wastewater and treated water characteristics, and Fig. 1 shows the wastewater treatment scheme.

The treatment plant has the following units:

1. Sump tank: reinforced cement concrete, rectangular shape underground tank, size $(3 \times 2 \times 2) \mathrm{m}$, having two submerged sludge pumps (one as standby) each of $0.75 \mathrm{~kW}$ motor for feeding raw wastewater.

2. PST: rectangular shaped MS tank, size $(3 \times 1 \times 2.25)$ $\mathrm{m}$, fitted with one SS turbine plate stirrer with $0.19 \mathrm{~kW}$ motor.

3. Chemical dosing tanks: three tanks each of 1001 capacity with total 3 dosing pumps (1 pump as standby) having $0.19 \mathrm{~kW}$ motor.

4. RBC: tank of size $(2 \times 0.8 \times 0.8) \mathrm{m}$; discs fitted with a worm gear motor of $0.19 \mathrm{~kW}$.
Fig. 1 Process flow diagram of the WWTP

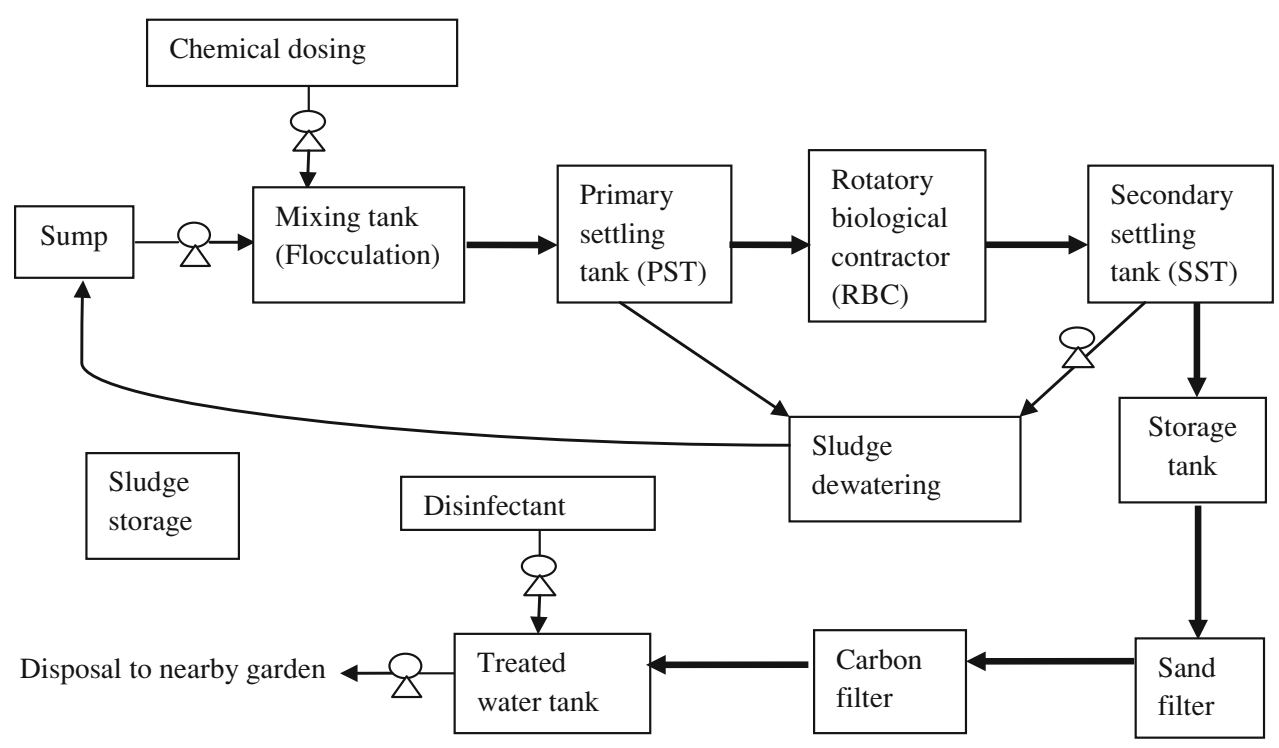


5. Disinfectant tanks: two tanks each of 1001 capacity with total 3 dosing pumps (1 pump as standby) having $0.19 \mathrm{~kW}$ motor.

6. SST: tank of size $(3 \times 1 \times 2.25) \mathrm{m}$, fitted with SS turbine plate stirrer $0.19 \mathrm{~kW}$ motor and single stage monoblock recirculation pump of $0.38 \mathrm{~kW}$.

7. Sand filter and carbon filter: 2001 capacity, fiberglass reinforced plastics (FRP) vessel with manual multiport valve.

8. Treated water tank: RCC rectangular, $(3 \times 2 \times 2) \mathrm{m}$, having one centrifugal regenerating pump of $0.75 \mathrm{~kW}$.

\section{Methodology and data collection}

Energy consumed during the treatment process is observed to be in the form of electrical, manual, chemical, and mechanical energy. Chemical energy can be considered as indirect energy, human or manual energy as renewable energy and others as non-renewable energy. Each form of energy consumption is calculated in terms of $\mathrm{kWh} / \mathrm{m}^{3}$ of wastewater treated. Primary data have been collected through field monitoring and corroborated with historical data through discussions with plant operators. Log-book and records of transactions and consumptions are also referred for validation. Field monitoring has been done for 15 days spread over 2 months during June-July, 2011. Equal representation of weekdays and weekends is considered for the monitoring days. Time measurement is done using a stopwatch.

\section{Estimation of electrical energy input}

The electrical energy input is estimated by considering the electrical load of the pump/motor $(\mathrm{kW})$, time in hours (h) for which the motor is operated and total amount of wastewater treated (Eq. 1).

$E_{\mathrm{p}}=\frac{P \times T}{Q}$

where, $E_{\mathrm{p}}$ is the electrical energy $\mathrm{kWh} / \mathrm{m}^{3}, Q$ the total flow of wastewater in $\mathrm{m}^{3} /$ day, $P$ the rated power of the electrical motor in kilo Watt $(\mathrm{kW})$, and $T$ is the operation hours in a day (h/day).

The motor efficiency is assumed as $80 \%$ (Fadare et al. 2010). Table 2 shows the average of values as obtained in the field.

\section{Estimation of manual energy input}

Manual energy is required for different activities on field like operating the switches, opening/closing of the sludge
Table 2 Details of mechanical equipment specification

\begin{tabular}{llllc}
\hline Treatment unit & $\begin{array}{l}\text { Type of } \\
\text { equipment }\end{array}$ & $\begin{array}{l}\text { No. of } \\
\text { working units }\end{array}$ & $P(\mathrm{~kW})$ & $\begin{array}{l}T(\mathrm{~h} / \\
\text { day })\end{array}$ \\
\hline $\begin{array}{l}\text { Raw water } \\
\text { collection sump }\end{array}$ & Pump & 1 & 0.75 & 6.5 \\
$\begin{array}{c}\text { Primary treatment } \\
\text { Chemical dosing }\end{array}$ & Stirrer & 1 & 0.19 & 11.75 \\
$\quad$ Pump & 2 & 0.19 & 2.4 \\
$\begin{array}{l}\text { RBC treatment } \\
\text { Secondary }\end{array}$ & Motor & 1 & 0.19 & 11.75 \\
treatment & Stirrer & 1 & 0.19 & 12.25 \\
& Recirculation & 1 & 0.38 & 5.45 \\
$\begin{array}{l}\text { Disinfectant tanks } \\
\text { Treated water } \\
\text { sump }\end{array}$ & $\begin{array}{l}\text { Pump } \\
\text { Pump }\end{array}$ & 2 & 0.19 & 2.1 \\
\hline
\end{tabular}

Table 3 Human power equivalent (E) in kW (WHO 1985)

\begin{tabular}{lllll}
\hline Lnput & Male & Female & Activities in the treatment plant \\
\hline Light & 0.13 & 0.10 & $\begin{array}{l}\text { Switch on/off the raw water pump, } \\
\text { maintain the log-book, check motor } \\
\text { temperature }\end{array}$ \\
Heavy & 0.54 & 0.44 & 0.11 & $\begin{array}{l}\text { Open/close the sludge drain valve, } \\
\text { operation of valves for backwashing, } \\
\text { Prepare the chemical solution for dosing, } \\
\text { fill the chemical solution in the dosing } \\
\text { tank, collect the dried sludge in gunny } \\
\text { bags }\end{array}$ \\
\hline
\end{tabular}

valves, cleaning of the tanks, operating valves to remove the sludge from the tank and collection of sludge in gunny bags to send it to the nearby horticultural garden. Manual energy consumption is a function of the gender of the labor and the nature of activity (Table 3). Based on these considerations, the manual energy is calculated using Eq. 2 . The data of field observation (total no. of hours taken to perform the activity) of manual energy are given in Table 4. In the study plant, no female labor is engaged.

$E_{m}=\frac{\sum_{i=0}^{i=n} \sum_{j=0}^{j=m} E_{i j} N_{i j} T_{i j}}{Q}$

where, $E_{\mathrm{m}}$ is manual energy in $\mathrm{kWh} / \mathrm{m}^{3}, n$ the number of nature of activities (light, active, and heavy), $m$ the number of gender (male, female), $E$ the human power equivalent $(\mathrm{kW}), N$ the number of persons engaged in an activity and $T$ is the total time devoted in the activity (h/day).

Estimation of fuel energy

Mechanical energy $\left(E_{\mathrm{f}}\right)$ in $\mathrm{kWh} / \mathrm{m}^{3}$ is calculated using Eq. (3) 
Table 4 Manual labour input in WWTP

\begin{tabular}{|c|c|c|}
\hline Treatment unit & $\begin{array}{l}\text { Nature of } \\
\text { activity }\end{array}$ & $\begin{array}{l}\text { Average labour } \\
\text { time input (h/day }\end{array}$ \\
\hline \multirow[t]{3}{*}{ Raw water collection sump } & Light & 0.5 \\
\hline & Medium & - \\
\hline & Heavy & - \\
\hline \multirow[t]{3}{*}{ Primary treatment } & Light & - \\
\hline & Medium & 1.5 \\
\hline & Heavy & 0.5 \\
\hline \multirow[t]{3}{*}{ Chemical dosing tank } & Light & 2.0 \\
\hline & Medium & - \\
\hline & Heavy & 1.08 \\
\hline \multirow[t]{3}{*}{$\mathrm{RBC}$ treatment } & Light & - \\
\hline & Medium & 0.06 \\
\hline & Heavy & 0.06 \\
\hline \multirow[t]{3}{*}{ Secondary treatment } & Light & - \\
\hline & Medium & 0.28 \\
\hline & Heavy & 0.28 \\
\hline \multirow[t]{3}{*}{ Storage tank } & Light & - \\
\hline & Medium & - \\
\hline & Heavy & 0.3 \\
\hline \multirow[t]{3}{*}{ Sludge storage tank } & Light & - \\
\hline & Medium & - \\
\hline & Heavy & 1.25 \\
\hline \multirow[t]{3}{*}{ Sand filter } & Light & 2 \\
\hline & Medium & - \\
\hline & Heavy & - \\
\hline \multirow[t]{3}{*}{ Carbon filter } & Light & 2 \\
\hline & Medium & - \\
\hline & Heavy & - \\
\hline
\end{tabular}

$E_{\mathrm{f}}=\frac{15.64 D}{Q}$

where, 15.64 is the unit energy value of diesel in $\mathrm{kWh} / \mathrm{l}$ (Devi et al. 2007a) and $D$ is the amount of diesel consumed in $1 /$ day.

Diesel consumption is found to be $5 \mathrm{l} / \mathrm{month}$ for oiling and repairing of machineries.

Estimation of chemical energy

Energy is, energy released or absorbed during a chemical reaction. Chemical energy is calculated by estimating the standard enthalpy (heat) of reaction $(\Delta H)$ of the chemicals during a reaction.

Chemical energy $\left(E_{\mathrm{c}}\right)$ in $\mathrm{kWh} / \mathrm{m}^{3}$ is calculated using Eq. (4)

$E_{\mathrm{c}}=\frac{n\left[\sum \Delta H_{\mathrm{p}}-\sum \Delta H_{\mathrm{r}}\right]}{Q} \times 0.000278$
Table 5 Chemicals used in WWTP

\begin{tabular}{llll}
\hline Unit & Chemical Name & Form & Quantity \\
\hline Mixing tank (flocculation) & $\begin{array}{l}\text { Caustic soda } \\
\text { Aluminium sulphate }\end{array}$ & $\begin{array}{l}\text { Powder } \\
\text { Treated water tank }\end{array}$ & $\begin{array}{l}\text { Powder } \\
\text { Sodium hypo } \\
\text { chloride }\end{array}$ \\
\hline
\end{tabular}

Table 6 Total Energy consumption for the WWTP

\begin{tabular}{lllll}
\hline Unit & $\begin{array}{l}\text { Electrical } \\
\text { energy } \\
\left(\mathrm{kWh} / \mathrm{m}^{3}\right)\end{array}$ & $\begin{array}{l}\text { Manual } \\
\text { energy } \\
\left(\mathrm{kWh} / \mathrm{m}^{3}\right)\end{array}$ & $\begin{array}{l}\text { Chemical } \\
\text { energy } \\
\left(\mathrm{kWh} / \mathrm{m}^{3}\right)\end{array}$ & $\begin{array}{l}\text { Total } \\
\text { energy } \\
\left(\mathrm{kWh} / \mathrm{m}^{3}\right)\end{array}$ \\
\hline Sump & 0.20 & 0.003 & 0.00 & 0.203 \\
PST & 0.09 & 0.019 & 0.096 & 0.205 \\
Dosing tank & 0.04 & 0.046 & 0.00 & 0.086 \\
RBC & 0.09 & 0.002 & 0.00 & 0.092 \\
$\begin{array}{l}\text { SST } \\
\text { Disinfectant } \\
\text { tank }\end{array}$ & 0.17 & 0.008 & 0.00 & 0.178 \\
$\begin{array}{l}\text { Sand filter } \\
\text { Carbon filter }\end{array}$ & 0.00 & 0.006 & 0.00 & 0.036 \\
$\begin{array}{c}\text { Treated } \\
\text { water tank }\end{array}$ & 0.18 & 0.010 & 0.00 & 0.010 \\
$\begin{array}{c}\text { Sludge } \\
\text { storage }\end{array}$ & 0.00 & 0.010 & 0.00 & 0.010 \\
$\quad$ tank & & 0.00 & 0.003 & 0.183 \\
\begin{tabular}{l} 
Total \\
\hline
\end{tabular} & 0.80 & 0.131 & 0.099 & 1.030 \\
\hline
\end{tabular}

where, $n$ is the number of moles (mol/day), 0.000278 is the conversion factor from $\mathrm{KJ}$ to $\mathrm{kWh}, \Delta H_{\mathrm{p}}$ the enthalpy (heat) of formation of products $(\mathrm{kJ} / \mathrm{mol})$, and $\Delta H_{\mathrm{r}}$ is enthalpy (heat) of formation of reactants $(\mathrm{kJ} / \mathrm{mol})$.

Table 5 shows the chemicals used and their respective quantities for treatment.

\section{Results and discussion}

Table 6 gives the assessment of energy consumption pattern in each treatment operation. In addition, the fuel energy (diesel) for entire treatment process is estimated at $0.036 \mathrm{kWh} / \mathrm{m}^{3}$. Therefore, the total energy consumption is $1.07 \mathrm{kWh} / \mathrm{m}^{3}$ of wastewater treated. It is much less as compared to the value obtained in a WWTP in California, which was reported to be $1.69 \mathrm{kWh} / \mathrm{m}^{3}$ excluding manual energy (Stokes and Horvath 2010). There are certain findings that are significant from the point of view of energy planning. First, the electrical form of energy has the biggest share (52\%) of all the forms of energy consumed 
in the treatment process. However, this is only about half of the total energy consumption. Therefore, electrical energy is not the only form of energy that should be considered in the energy benchmarking exercise. Several studies (for e.g. Devi et al. 2007b; Jonasson 2007; Middlebrooks et al. 1981) have considered only the electrical energy and therefore their results do not present the complete energy scenario of a treatment process. The electrical energy consumption per cubic meter of wastewater treatment is found to be $0.80 \mathrm{kWh} / \mathrm{m}^{3}$. It is commensurate with the findings of several other studies on WWTPs. The values vary in the range of $0.26-0.84 \mathrm{kWh} / \mathrm{m}^{3}$ (Venkatesh and Brattebo 2011; Pan et al. 2011; Friedrich et al. 2008). The evidences from the literature suggest that the electrical energy consumption can vary by a factor of 1.6 depending upon the choice of the technology and the scale of operation. The major source of electrical energy consumption is in the pump house (79\%) where raw wastewater pumps and treated water pumps have a significant share. Biological treatment process consisting of RBC process consumes $11 \%$ of the total electrical energy consumption.

Second, manual form of energy has the second highest share $(32 \%)$ during the treatment process. Most of it is used for light work $(45 \%)$ followed by heavy work $(39 \%)$. Highest amount of manual energy (35\%) is consumed during the preparation of chemicals for dosing tank. $21 \%$ of manual energy is used for removing the sludge from the sludge tank and disposing to the nearby garden. Looking to the energy pattern of manual energy, it is evident that this form of energy contributes to the total energy consumption and it is inevitable. Third, chemical energy and mechanical energy have insignificant share of 7 and $9 \%$, respectively.

Amongst the treatment processes, the raw water collection sump and primary settling tank consume maximum amount of energy (20\%). The energy used here is for pumping the raw water from the sump to the primary settling tank. The disinfectant tank, sand filter and carbon filter account for the least energy consumption. Primary settling tank, secondary settling tank and the treated water tank consume almost the same amount of energy. The treated water tank consumes $(18 \%)$ as the sump is made below the ground level and secondary settling tank consumes $(17 \%)$ electrical energy. Dosing tanks and the sludge storage tank consume the highest amount of manual energy of 31 and $21 \%$, respectively. The energy consumed here is for mixing and preparing the chemicals in dosing tanks and removing the dried sludge in gunny bags to the nearest horticulture garden. Primary settling tank uses the highest amount of chemical energy (79 \%) for flocculation and coagulation. Direct energy has $91 \%$ share and renewable energy has $12 \%$.

\section{Conclusions}

The energy pattern analysis of a small-scale WWTP has been analysed. The energy consumption is found to be about $1.046 \mathrm{kWh} / \mathrm{m}^{3}$ of wastewater treatment. This is significantly less than the values reported in the literature for large-scale WWTP. Further, previous studies have not included manual energy consumption in their analysis. It is found to be about $32 \%$ of the total energy consumption. There is a lot of variation in the reported values in the literature. The plausible reason is that the energy intensity depends on the capacity of the treatment plant, extent of automation, and choice of treatment technology. This suggests that a number of such investigations are required for various categories of treatment plants so as to have a holistic view on the wastewater treatment and energynexus. Based on the evidence of this study, it can be stated that the decentralized treatment systems have less energy intensity in comparison to a large-scale plant. This could be partly attributable to the use of manual energy in the treatment process in a small-scale plant. However, such a generalization needs to be supported with a number of analyses for various types of treatment processes and wastewater characterization in various regions of the world.

Acknowledgments The authors thank the Ministry of New and Renewable Energy (MNRE, Govt. of India, New Delhi) for providing financial support for the study. The authors are also grateful to the officials and WWTP operators at TERI University for their assistance and co-operation in carrying out this study and providing relevant data.

Open Access This article is distributed under the terms of the Creative Commons Attribution License which permits any use, distribution, and reproduction in any medium, provided the original author(s) and the source are credited.

\section{References}

Devi R, Dahiya RP, Kumar A, Singh V (2007a) Meeting energy requirement of wastewater treatment in rural sector. Energy policy 35:3891-3897

Devi R, Singh V, Dahiya RP, Kumar A (2007b) Energy consumption pattern of a decentralized community in northern Haryana. Renew Sustain Energy Rev 13:194-200

Fadare DA, Nkpubre DO, Oni AO, Falana A, Waheed MA, Bamiro OA (2010) Energy and exergy analyses of malt drink production in Nigeria. Energy 35:5336-5346

Food and Agriculture Organization, World Health Organization, and United Nations University (FAO/WHO/UNU) (1985) Energy and Protein Requirements. Report of Joint FAO/WHO/UNU Expert Consultation. WHO Technical Report Series No. 724. Geneva: World Health Organization

Friedrich E, Pillay S, Buckley CA (2008). Environmental life-cycle assessments for water treatment processes-a South African case study of an urban water cycle. http://www.assaf.co.za/wpcontent/uploads/2010/04/WaterSAJan09.pdf 
Hellstrom D (1997) An exergy analysis for a wastewater treatment plant: an estimation of the consumption of physical resources. Water Environ Res 69(1):44-51

Jonasson M (2007) Energy benchmark for wastewater treatment process - a comparison between Sweden and Austria. Dissertation. Department of Industrial Electrical Engineering and Automation, Lund University, Lund

Mahgoub M, El SM, Steen NPVD, Zeid KA, Vairavamoorthy K (2010) Towards sustainability in urban water: a life cycle analysis of the urban water system of Alexandria City, Egypt. J Clean Prod 18:1100-1006

Merlin G, Lissolo T (2010) Energy and exergy analysis to evaluate sustainability of small wastewater treatment plants: application to a constructed wetland and a sequencing batch reactor. J Water Resour Prot 2:997-1009
Middlebrooks E, Middlebrooks H, Reed S (1981) Energy requirement for small wastewater treatment systems. Water Pollut control Fed 53(7):1172-1197

Pan T, Zhu D-X, Ye P-Y (2011) Estimate of life-cycle greenhouse gas emissions from a vertical subsurface flow constructed wetland and conventional wastewater treatment plants: a case study in China. Ecol Eng 37:248-254

Stokes RJ, Horvath A (2010) Supply chain environmental effects of wastewater utilities. Environ Res Lett 5:014015 (7 pp)

Venkatesh G, Brattebo H (2011) Energy consumption, costs and environmental impacts for urban water cycle services: case study of Oslo (Norway). Energy 36:792-800 